\title{
Research on the Influence Factors of the Service Satisfaction in University Campuses in China: A Review
}

\author{
Yanan Sun 1,2, Qing Gao² \\ ${ }^{1}$ School of Economics and Management, Southwest Jiaotong University, Chengdu, China \\ ${ }^{2}$ Department of Logistics Support, Southwest Jiaotong University, Chengdu, China \\ Email: syn19811027@163.com
}

Received 23 September 2015; accepted 17 November 2015; published 20 November 2015

Copyright @ 2015 by authors and Scientific Research Publishing Inc.

This work is licensed under the Creative Commons Attribution International License (CC BY). http://creativecommons.org/licenses/by/4.0/

c) (i) Open Access

\begin{abstract}
Based on the research overview on the service satisfaction of university campuses at home and abroad in recent years, this paper comprehensively expounds the research status of the service satisfaction of campuses, and proceeds with the outlook of the research prospect on the evaluation system of the service satisfaction in the hope that it can have a certain significance for theory reference in researching and establishing the evaluation system of the service satisfaction in university campuses in China.
\end{abstract}

\section{Keywords}

University, Campuses' Service, Satisfaction, Service Quality, Overview

\section{Introduction}

With the economic booming of China, the business of Chinese higher education also springs up. According to the educational statistics released by National Bureau of Statistics of China, there were 25,477,000 undergraduates and college students and 1,848,000 graduate students in school in 2014 [1]. Faced with such a large group of service objects, security services of campuses, as the basic security of university work, encounter with a huge test. The expectation of universities on campus services is to provide superior, convenient and satisfactory services to teachers and students in schools, which is also the goal pursued by campus services of universities. This article summarizes research results related to service satisfaction in campuses of universities at home and abroad in recent years, and combines with research status to have the outlook of researching and establishing the evaluation system of the service satisfaction in university campuses in China in the future. 


\section{Related Theories}

\subsection{Theories of Customer Satisfaction and Evaluation Model}

\subsubsection{Customer Satisfaction}

Cardozo (1965) [2] considers that satisfaction is the result of expectation, while expectation is partly derived from previous experience. In other words, expectation is from the experience, which can be adjusted by the efforts of customers. In the opinion of Howard \& Sheth (1969) [3], they believe that satisfaction is a kind of recognition condition whether the compensation obtained by sacrificing others by buyers is appropriate or not. This definition includes the two components, namely, appraisal and comparison. Oliver (1980) [4] holds the idea that satisfaction is a temporary and emotional reaction of consumers to matters. Westbrook (1981) [5] thinks that satisfaction is a kind of cognitive appraisal process in the comparison between the actual product performance and the previous expectation by customers. Churchill \& Surprenant (1982) [6] consider that satisfaction of customers is a result of the purchase and use, which is produced by the comparison of the remuneration of expected results and the investment costs by buyers. Cadotte, Woodruff\& Jenkins (1987) [7] deem that consumers will use emotional statements to express the positive or negative emotion on the usage of products, thereby affecting their satisfaction. Fornell (1992) [8] believes that satisfaction of customers is the overall appraisal of the experience in purchasing from products or services. The research group of PZB (Parasuraman, Zeithaml \& Berry) considers that customer satisfaction is determined by the gap between the services that customers actually feel and the expected services. Kolter (1994) [9] holds the idea that satisfaction is the feeling level of a person, and it is the result of comparing perceived performance and expectation of products. Spreng, Mackoy \& Harrell (1995) [10] deem that satisfaction is not only a kind of emotion. Moreover, it is a kind of conception of emotional evaluation and quasi cognition. Woodruff (1997) [11] believes that the comparison standard should base on the value yearned by customers which dates from the property, performance and results of products. The judgment of satisfaction on customers should take the expected value hierarchy of customers established before purchasing as the foundation. International Organization for Standardization (ISO) pushes the concept of customer satisfaction by quality standards of 1S09000: customer satisfaction is the degree of satisfaction that customers' requirements have been met, including ostensive, connotative or performing demands or expectation.

\subsubsection{Evaluation Model of Customer Satisfaction}

1) Foreign Evaluation Model of Customer Satisfaction

Oliver \& Desarbo (1988) [12] think that the mainstream of the research on customer satisfaction can be divided into three categories, including inconsistent and deformed expectation, the model of compensation process, and other perspectives:

(1) Theory of customer satisfaction in inconsistent and deformed expectation: Anderson (1973) [13] summarizes reasons for the formation of the theory, including assimilation theory by Festinger (1957) [14], contrast theory by Hovland (1957) [15], assimilation-contrast theory by Parasuraman, Zeithaml \& Berry (1991), and generalized negativity theory by Smith \& Aronsom (1963) [16] and Howard \& Sheth (1969) [3].

(2) Theory of customer satisfaction in the compensation process is proposed by Day \& Landon (1977) [17], and Richins (1983) [18]. The theory of the compensation process mainly studies that customers will take what kind of action to obtain the compensation process when they are dissatisfactory; furthermore, it also indirectly researches the process of the impact of customer satisfaction on the post-purchase behavior, which is the biggest difference from the above-mentioned theories

(3) Theory of customer satisfaction in other perspectives: the modes of customer satisfaction in other perspectives include equity theory by Oliver \& Desarbo (1988) [12] and Huppertz, Renson \& Evans (1978) [19], attribution theory by Bitner (1990) [20] and Weiner, Russell \& Lerman (1979) [21], performance theory by Olshavsky \& Miller (1972) [22], Westbrook (1981) [5], Tse \& Wilton (1988) [23] and Hirschman \& Holbrook (1982), emotional and cognitive theory by Oliver (1993) [24], and the model of customer satisfaction with the combination of antecedents and consequences by Heskekk, Jones, and Loveman et al (1994) [25].

\section{2) Chinese Evaluation Model of Customer Satisfaction}

China began to study Customer Satisfaction Index (CSI) from 1995. The concept of CSI was initially introduced by the Professor Zhao Ping from Tsinghua University. In 1998, China State Bureau of Quality Technical Supervision (CSBTS) commissioned School of Economics and Management of Tsinghua University to carry out the research work about the establishment of CSI in China. From 2000 to 2002, State Administration for Quality 
Supervision and Inspection and Quarantine (AQSIQ) and the Chinese Enterprise Research Center of Tsinghua University had jointly undertaken to carry out the Research on the Construction Method of CSI in China, and put forward the model of Chinese customer satisfaction index (CCSI for short) [26].

\subsection{Definition, Evaluation Factors and Evaluation Model of Service Quality}

\subsubsection{Definition of Service Quality}

Gronroos (1982) [27] considers that the essence of service quality is the perception of service objects or customers on services, which is the ratio between the expected services and actually perceptive services. Moreover, it is the subjective response of service objects to services. Garvin (1983) [28] divides service quality into five categories: 1) method of characteristics; 2) method of foundation; 3) user-based approach; 4) manufacturing-based approach; 5) value-based approach. In other words, service quality is the subjective response of consumers on matters, which can't be quantized and measured by the nature and characteristics of matters. The research group of PZB (Parasuraman, Zeithaml \& Berry, 1985) [29] considers that service quality is a kind of attitude, the appraisal of service quality is the perception of the attitude, which contains attitude evaluation in the process of service delivery as well as attitude evaluation after achieving the results of services. If the actual perception of the attitude is higher than the actual perception, it means that service quality is favorable. Lehtinen U. \& Lehtinen J. R (1991) [30] think that the subjective perception generated in the phase of accepting services is service quality, which is obtained by comparing the services obtained by actual perception and the expected services that should be provided by service providers in their opinion. Xu Jincan et al. (2002) [31] believe that the quality of service is the characteristic integration that services meet the needs of the service recipients. Xie Lishan et al. (2007) [32] hold the idea that service quality is a perceptual assessment of remarkable grade of services in accepting services by service-objects.

\subsubsection{Evaluation Factors and Evaluation Model of Service Quality}

\section{1) Factors of Service Quality}

The research group of PZB (Parasuraman, Zeithaml \& Berry, 1985) [29] believes that the quality of service should cover ten evaluation factors, including the tangibles, responsiveness, credibility, reliability, responsiveness, security, tangibles, access, communication and understanding. At the same time, they put forward the service quality gap analysis model SERVQUL, revise and optimize the model, and refine the original ten dimensions of service quality into the existing five dimensions in: 1) tangibles; 2) reliability; 3) responsiveness; 4) assurance; 5) empathy.

\section{2) Evaluation Model of Service Quality}

Fishbein model is used as the foundation to measure the tendency of attitudes of service accepters. In the meantime, it is applied to measure service quality targeting at the degree of attention and feelings to things of service accepters. Sasser model can take the hardware and software aspects of the service operation into account. Moreover, it also incorporates the visible parts including device, raw materials and personnel, ideas and other invisible parts for consideration. As for the model of Parasuraman, Zeithaml \& Berry (1985) [29], Parasuraman, Zeithaml and Berry define service quality as the gap between perceived performance of customers and expectations ( $\mathrm{SQ}=\mathrm{P}-\mathrm{E}$ ), and propose the gap model of performance and expectations. The research group of PZB (1985) comes up with the idea that service quality can be measured by ten factors, and integrates the ten factors into five factors in 1988. Furthermore, the research group of PZB (1988) studies five levels of SERVQUAL in 1991 again, and put forward the method for measuring service quality by the amendments of SERVQUA. In the empirical results, the measure method of adequacy-importance is a favorable measure model (Cronin \& Taylor, 1992) [33]. Although SERVPERF model is not as detailed and explicit as the above-mentioned models in the usage, it can clearly evaluate service quality since it can measure the performance of execution results of services in the virtue of simplification. Brown, Churchill \& Peter (1993) [34] disagree with the idea in SERVQUAL that the gap between perceived services and expected services is served as the method of measuring the service quality. Moreover, they think it will make the service quality become the third variable, following the two variables - the cognitive services and the expected services. Therefore, they suggest that the gap between perceived service and expected service in customers' mind should be directly measured and serve as the service quality. In the dynamic model, Boulding, Kalra, Staelin et al. (1999) [35] consider that the supported expectation should be the manifested service level in the ideal situation, while the coming expectation is that the service 
level might be showed in the real state in customers' opinion. Since those two can evaluate customer psychological process, they can confirm the customers' perception on service quality.

Although the domestic theoretical researches in the field of service quality starts lately, many scholars have carried out a lot of applied researches and empirical researches on the theories of foreign countries, and also put forward some ideas of their own. Taiwan scholars He Yongqing and Su Yunhua (1995) [36] have proposed the method to measure the quality of service for consumers to repeatedly receive the service rate. For example, in the empirical research on the services of hotel industry and newspaper industry, Wei Fuxiang (2002) [37] verifies the viewpoint of Caruana \& Berthon et al., namely, the perceived service quality of customers has low correlation with the repurchase intention of customers. Wang Chunxiao, Wen Biyan and Jiang Caifen (2001) [38] show that service quality, consumption value and customer satisfaction have a direct impact on the behavior intention of customers, and point out that these four different concepts are the sub concepts of consumption experience of tourism services through the empirical research.

\section{Research Status of Service Quality Evaluation in Universities}

\subsection{Foreign Research Status}

There are few literatures about the evaluation of service quality in university campuses, Owlia (1996) [39] establishes the model for the concept of higher education services, starts from characteristics of services of higher education, and divides service evaluation of higher education into service facilities, service ability, service attitude, service content, the process of services and reliability. In addition, Ford (1999) [40], Oldfield \& Baron (2000) [41], Wright \& O’Neill (2002) [42], Lagrosen (2004) [43] and Athiyaman (2006) [44] also distinguish the service quality of higher education in different aspects. Anderson (1995) [45] employs SERVQUAL questionnaire to appraise the discrepancy of service quality of university students on college education. Mathew \& Beatriz (1999) et al. [46] adopt important-performance model to analyze the service quality of higher education.

\subsection{Chinese Research Status}

Gui Lingling (2005) [47] applies the theories related to institutional economics to analyze the shortcomings of the traditional campus system from the perspective of institutional arrangements and institutional environment, and believes that the socialization reform policy of campus management of institutions of higher learning is not perfect. Through the analysis of the specific factors and forms affecting the implementation of the policy, we should carry out with the specific recommendations targeting at the socialization reform of university campuses. Chinese inherent idea that schools run the society can not meet the needs of the development of universities in new era. Therefore, the socialization reform of university campuses is imperative (Wang Liguo, Zhang Wenhan, 2007) [48].

Guo Lingling (2004) [49] proposes that the service quality system of university campuses can be divided into the system of service evaluation index and the system of economic evaluation index. Through endowing reasonable weights to those two systems, we can get the comprehensive assessment scores of service quality in university campuses. However, this study does not give a specific and operable evaluation index system. Hu Tiewei (2004) [50] employs the method with the combination of quantitative and qualitative analyses, and puts forward the specific reform direction against the existing problems in campuses from three aspects-the scientific management system, legal person system and self restraint system, which aims for the enterprization of university campuses. Moreover, he also establishes the evaluation model of reform performance in university campuses, and selects a university in China for the empirical analysis in order to provide a scientific basis for the profound reform of the enterprization of university campuses. Ji Xiaoyi and Huang Xiaoping (2005) [51] conduct a survey on the satisfaction evaluation of education service quality in universities, establish the evaluation index system of customer satisfaction, and apply the method of AHP to conduct comprehensive assessment on customer satisfaction in universities. In the literature, the campus security, one of indicators of investigation item, is analyzed by quantitative evaluation. Lin Weiying (2005) [52] researches on the perceived quality of serves of college students, and studies the problem of customers' perceived quality in the model of customer satisfaction index. Li Fayou et al. (2009) proposes a model system for evaluating the serve satisfaction in campuses based on the relevant literature review. Guo Linsong et al. (2010) [53] makes an analysis on the necessity and significance of establishing the evaluation index system of service satisfaction in campuses, and tries to establish the 
evaluation index system of service satisfaction in university campuses (see Table 1). Yuan Liang et al. (2012) [54] conduct an empirical research on the construction of the evaluation index system of service satisfaction in university campuses (see Table 2). Gao Qing (2012) [55] carries out an empirical study on the service satisfaction in the student canteen based on college students' consumption behavior, establishes the service satisfaction model of college students from the perspective of catering service research.

\section{Conclusion}

The theoretical significance of the Service Satisfaction research in university campuses was to establish and perfect the customer satisfaction model of university campus, analyze the influence factors with the model, specific conditions of use of the model, and enlarge the using range of the model. In addition, the author thinks that the research has its practical significance, including: (1) To optimize of the overall work in university campuses. The customer satisfaction research in university campuses is helpful to find out the shortage of the service in University Campuses, and it is also helpful to improve management level and competitive ability of the university;

Table 1. Evaluation index of the serve satisfaction in campuses proposed by Guo Linsong et al. (2010) [53].

\begin{tabular}{|c|c|c|}
\hline \multirow{7}{*}{1} & & Dining environment \\
\hline & & Tableware hygiene \\
\hline & & Price tag \\
\hline & Catering services & Food prices \\
\hline & & Food quality \\
\hline & & Variety and emaciated look of food \\
\hline & & Service attitude of dining \\
\hline \multirow{7}{*}{2} & & Environment of living area \\
\hline & & Sanitation in apartment buildings \\
\hline & & Construction of apartment culture \\
\hline & Apartment services & Timeliness of apartment maintenance \\
\hline & & Quality of apartment maintenance \\
\hline & & Water supply service \\
\hline & & service attitude of accommodation \\
\hline \multirow{6}{*}{3} & \multirow{6}{*}{ Public services } & Sanitation of community Environment \\
\hline & & Sanitation of teaching buildings \\
\hline & & Campus greening \\
\hline & & Living area greening \\
\hline & & accuracy of sending and receiving newspapers and magazines \\
\hline & & Public service attitude \\
\hline \multirow{6}{*}{4} & \multirow{6}{*}{ Maintenance services } & Stability of hydropower operation \\
\hline & & Operation stability of elevators \\
\hline & & Maintenance timeliness \\
\hline & & Maintenance quality \\
\hline & & Civilized construction \\
\hline & & Service attitude of maintenance \\
\hline
\end{tabular}


Table 2. Evaluation index of the serve satisfaction in campuses raised by Yuan Liang et al. (2012) [54].

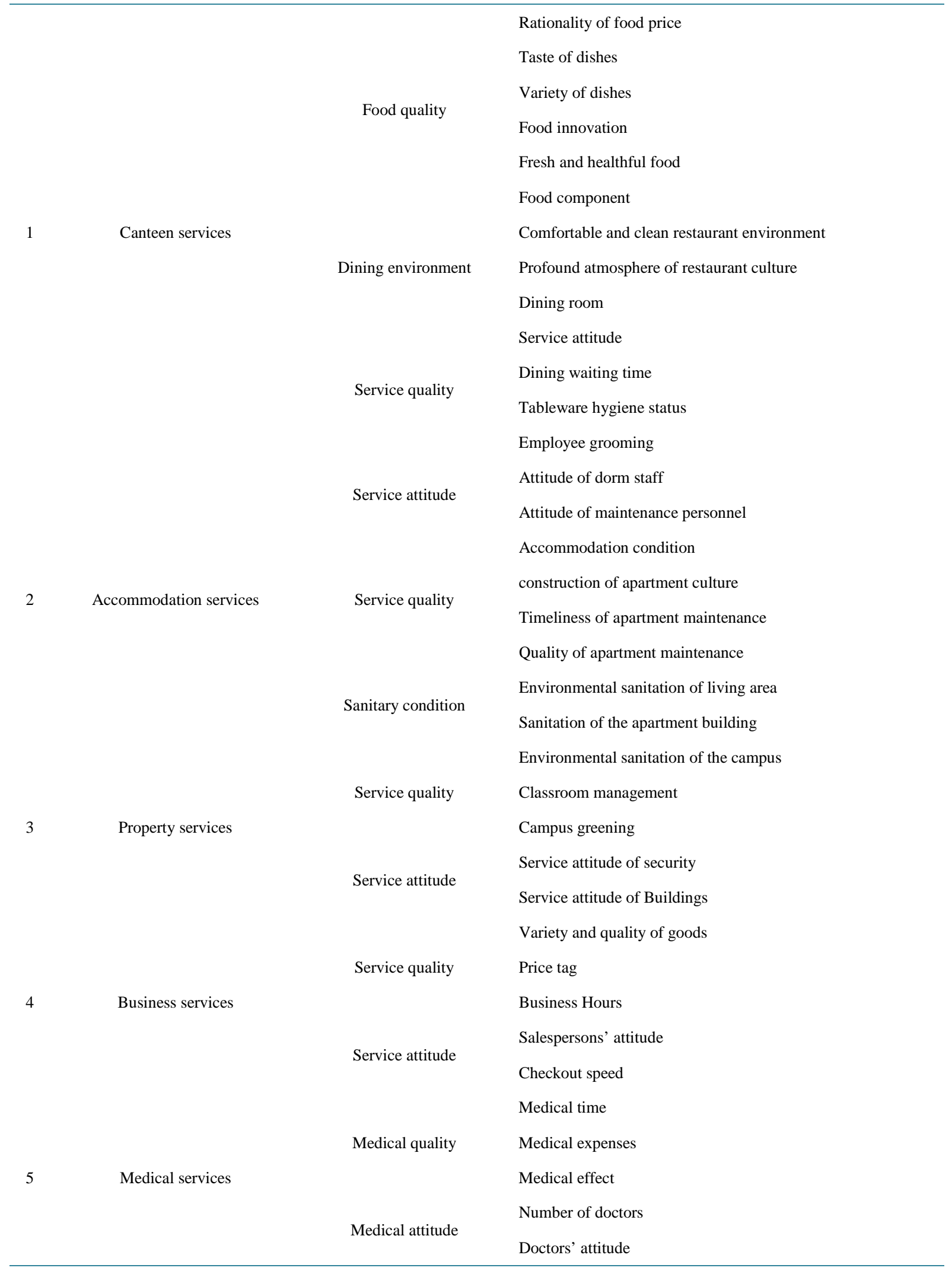


(2) To increase the student source and improve the quality of the student source. Only if a university constantly improves the internal customer and external customer satisfaction, can it improve the university's popularity and social recognition which help to get high quality student source; (3) To improve the school's reputation and create brand effect. The school's reputation directly affects the quality of student source, the employment rate of graduate and quality of teachers.

Achievements have been made in related research in China, however, there still exist many problems in the research and use of satisfaction surveys, such as lack of standardization and analysis benchmarking, emphasis on a specific service at the expense of the school's overall service quality, lack of psychological surveying and research on applicability and practicability, artificially introduced bias factor in conducting the surveys, oversimplified presentation of survey results, and limited use of information. In view of the above situations, we can conduct wide researches and analyses in the future researches to establish the evaluation index system of satisfaction in university campuses in China. By virtue of the method of factor analysis, we can analyze the influence factors of satisfaction in university campuses. Therefore, we can propose the evaluation index system of satisfaction to the general universities in extensive adaptability. Furthermore, we can conduct a questionnaire survey in Chinese universities, and validate its effectiveness and credibility through the structural equation model. The ultimate goal is to establish a comprehensive and universal evaluation index of service satisfaction in Chinese universities, and to propose a set of impeccable evaluation methods.

\section{Acknowledgements}

The research is supported by research fun of China Association for Campus Management (CACM) (No. YBKT2015008).

\section{References}

[1] National Bureau of Statistics of Statistics of the People's Republic of China (2015) Statistical Communiqué of the People's Republic of China on the 2014 National Economic and Social Development. http://www.stats.gov.cn/tjsj/zxfb/201502/t20150226_685799.html

[2] Cardozo, R.N. (1965) An Experimental Study of Customer Effort, Expectation, and Satisfaction. Journal of Marketing Research, 3, 244-249. http://dx.doi.org/10.2307/3150182

[3] Howard, J.A. and Sheth, J.N. (1969) The Theory of Buyer Behavior. John Wiley, New York, 12-15.

[4] Oliver, R.L. (1980) A Cognitive Model of the Antecedents and Consequences of Satisfaction Decisions. Journal Marketing Research, 4, 460-469. http://dx.doi.org/10.2307/3150499

[5] Westbrook, R.A. (1981) Source of Consumer Satisfaction with Retail Outlets. Journal of Retailing, 3, 68.

[6] Churchill Jr., G.A. and Superenant, C. (1982) An Investigation into the Determinants of Consumer Satisfaction. Journal of Marketing Research, 3, 491-504. http://dx.doi.org/10.2307/3151722

[7] Cadotte, E.R. (1987) Expectations and Norms in Models of Consumer Satisfaction. Journal of Marketing Research, 24, 305-314. http://dx.doi.org/10.2307/3151641

[8] Fornell, C. (1992) A National Customer Satisfaction Barometer: The Swedish Experience. Journal of Marketing, 1, 6-21. http://dx.doi.org/10.2307/1252129

[9] Kotler, P., Haider, D. and Rein, I. (1993) Marketing Places. Attracting Investment, Industry and Tourism to Cities, States, and Nations. Maxwell Macmillan Int, New York.

[10] Spreng, R.A., Harrell, G.D. and Mackoy, R.D. (1995) Service Recovery: Impact on Satisfaction and Intentions. Journal of Service Marketing, 1, 15-23. http://dx.doi.org/10.1108/08876049510079853

[11] Woodruff, R.B. (1997) Customer Value: The Next Source for Competitive Advantage. Journal of Academy of Marketing Science, 25, 139-153. http://dx.doi.org/10.1007/BF02894350

[12] Oliver, R.L. and De Sarbo, W.S. (1988) Response Determinants in Satisfaction Judgment. Journal of Consumer Research, 14, 495-507. http://dx.doi.org/10.1086/209131

[13] Chen, X. (2011) Research on the Relationship between Customer Satisfaction and Positive Word of Mouth. South China University of Technology, Guangzhou, 5-29.

[14] Festinger, L. (1957) A Theory of Cognitive Dissonance. Stanford University Press, Stanford, 58-63.

[15] Hovland, C. (1957) The Order of Presentation in Persuasion. Yale University Press, New Haven, 33-36.

[16] Qin, M. and Zheng, Y. (2009) The Negative Outcome of Psychotherapy. Advances in Psychological Science, 6, 13161326. 
[17] Day, R.L. and Landon, E.L. (1977) Consumer and Industrial Buying Behavior. North-Holland, New York, $426-437$.

[18] Richins, M.L. (1983) Negative Word-of-Mouth by Dissatisfied Consumers: A Pilot Study. Journal of Marketing Research, 47, 68-78. http://dx.doi.org/10.2307/3203428

[19] Huppertz, J.W. (1978) An Application of Equity Theory to Buyer-Seller Exchange Situations. Journal of Marketing Research, 15, 250-260. http://dx.doi.org/10.2307/3151255

[20] Bitner, M.J., Booms, B.H. and Tetreault, M.S. (1990) The Service Encounter: Diagnosing Favorable and Unfavorable Incidents. Journal of Marketing Research, 54, 71-84. http://dx.doi.org/10.2307/1252174

[21] Weiner, B., Russell, D. and Lerman, D. (1979) The Cognition-Emotion Process in Achievement-Related Contexts. Journal of Personality, 37, 1211-1220. http://dx.doi.org/10.1037/0022-3514.37.7.1211

[22] Olshavsky, R.W. and Miller, J.A. (1972) Consumer Expectations, Product Performance, and Perceived Product Quality. Journal of Marketing Research, 9, 19-21. http://dx.doi.org/10.2307/3149600

[23] Tse, D.K. and Wilton, P.C. (1988) Models of Consumer Satisfaction Formation: An Extension. Journal of Marketing Research, 25, 204-212. http://dx.doi.org/10.2307/3172652

[24] Oliver, R.L. (1993) Cognitive, Affective, and Attribute Bases of the Satisfaction Response. The Journal of Consumer Research, 20, 418-430. http://dx.doi.org/10.1086/209358

[25] Heskett, J.L., Jones, T.O., Loveman, G.W., et al. (1994) Putting the Service-Profit Chain to Work. Harvard Business Review, 72, 164-170.

[26] Jian, C.Y. (2005) The Customer Satisfaction Index Evaluation Mode: Comparison and Reference. Commercial Age, 11, 39-42.

[27] Gronroos, C. (1988) Service Quality: The Six Criteria of Good Perceived Service Quality. Review of Business, 9, 1013.

[28] Cronin, J.J. and Taylor, S.A. (1992) Measuring Service Quality: A Reexamination and Extension. Journal of Marketing Research, 56, 55-68. http://dx.doi.org/10.2307/1252296

[29] Parasuraman, A., Zeithaml, V.A. and Berry, L.L. (1985) A Conceptual Model of Service Quality and Its Implications for Future Research. Journal of Marketing Research, 49, 41-50. http://dx.doi.org/10.2307/1251430

[30] Lehtinen, U. and Lehtinen, J.R. (1991) Two Approaches to Service Quality Dimensions. Service Industries Journal, 11, 287-303. http://dx.doi.org/10.1080/02642069100000047

[31] Xu, J.C., Ma, M.C. and Chen, Y.W. (2002) Review on the Research of Service Quality. Advances in Psychological Science, 2, 233-239.

[32] Xie, L.S. and Li, J.Y. (2007) A Study of the Relationships between Tour Guides' Service Quality and Tourists’ Trust and Behavioral Intentions. Chinese Tourism Science, 4, 43-48.

[33] Cronin Jr., J.J. and Taylor, S.A. (1992) Measuring Service Quality: A Reexamination and Extension. Journal of Marketing Research, 56, 55-68. http://dx.doi.org/10.2307/1252296

[34] Brown, T.J., Churchill, G.A. and Peter, J.P. (1993) Research Note: Improving the Measurement of Service Quality. Journal of Retailing, 69, 127-139. http://dx.doi.org/10.1016/S0022-4359(05)80006-5

[35] Boulding, W., Kalra, A. and Staelin, R. (1999) The Quality Double Whammy. Marketing Science, 18, 463-484. http://dx.doi.org/10.1287/mksc.18.4.463

[36] Liu, J.J. (2014) Research on Customer-to-Customer Interaction’s Influence on Perceived Service Quality—Based on Entertain Industry’s Empirical Analysis. PhD Thesis, Huaqiao University, Quanzhou, 2-8.

[37] Wei, F.X. (2002) Exploratory Investigation to Service Recovery and Related Issues. Journal of Tianjin University of Commerce, 22, 24-26.

[38] Wang, C.J., Jiang, C.F. and Wen, B.Y. (2001) An Empirical Research on National Tourist Consumption. Journal of Beijing International Studies University, 3, 80-86.

[39] Zhang, Q.H. (2012) The University Logistic Services Quality Evaluation System—Northwest A\&F University as an Example. Master's Thesis, Northwest A\&F University, Yanglin, 12-15.

[40] Ford, J.B., Mathew, J. and Beatriz, J. (1999) Importance-Performance Analysis as a Strategic Tool for Service Marketers: The Case of Service Quality Perceptions of Business Students in New Zealand and the USA. The Journal of Services Marketing, 13, 171-186. http://dx.doi.org/10.1108/08876049910266068

[41] Oldfield, B.M. and Baron, S. (2000) Student Perceptions of Service Quality in a UK University Business and Management Faculty. Quality Assurance in Education: An International Perspective, 8, 85-95. http://dx.doi.org/10.1108/09684880010325600

[42] Liu, J.Y. (2009) Quality Management of Higher Education Based on Services Marketing Perspective. PhD Thesis, Tianjin University, Tianjin, 3-25. 
[43] Wang, C.H. and Wang, W. (2012) Review on the Research of Higher Education Service Quality. Chinese Education Forum, 33, 157-158.

[44] Athiyaman, A. (2006) Perceived Service Quality in the Higher Education Sector: An Empirical Analysis. In: ANZMAC 2000 Visionary Marketing for the 21st Century: Facing the Challenge, NP. NT: 5055.

[45] Anderson, E. (1995) High Tech v. High Touch: A Case Study of TQM Implementation in Higher Education. Managing Service Quality, 5, 48-56. http://dx.doi.org/10.1108/09604529510083576

[46] Ford, J.B., Joseph, M. and Joseph, B. (1999) Importance Performance Analysis as a Strategic Tool for Service Marketers: The Case of Service Quality Perceptions of Business Students in New Zealand and the USA. The Journal of Services Marketing, 13, 171-186. http://dx.doi.org/10.1108/08876049910266068

[47] Gui, L.L. (2005) Research on the University Logistic Socialization Policy. Master's Thesis, Zhengzhou University, Zhengzhou, 25-57.

[48] Wang, L.G., Zhang, W.H. and Wang, Y.B. (2007) Analysis of the College Logistics Socialization Reform Mode. Chinese University Logistics Research, 3, 19-21.

[49] Guo, L.L. (2004) Construction of the University Logistics Entity Appraisal Model. Chinese Business Accounting, 4, 22-24.

[50] Hu, T.W. (2004) Research on the Enterprise reform of the University Logistic Management. Master's Thesis, Tianjin Normal University, Tianjin, 5-7.

[51] Ji, X.Y. and Huang, X.P. (2005) Research on Customers' Satisfaction Degree in Higher Education Institutions. Higher Education Development and Evaluation, 4, 29-32.

[52] Lin, W.Y. (2005) Research on Students’ Perception of Service Quality. PhD Thesis, Tianjin University, Tianjin, 1-22.

[53] Guo, L.S., Fang, C.S. and Liu, N. (2010) The Construction of Evaluation Index System of University Logistics Service Satisfaction. Science \& Technology Information, 33, 392-393.

[54] Yuan, L., Jia, B. and Qian, Z.H. (2012) Research on Service Satisfaction in University Campuses. Market Weekly (Theory), 12, 31-32.

[55] Gao, Q. (2012) Satisfaction Research for Student Canteen Service Based on College Students' Diet Consuming Behavior. PhD Thesis, Southwest Jiaotong University, Chengdu, 18-26. 